\title{
Language Disorders in Children with Iron Deficiency Anemia
}

\author{
Original \\ Article \\ Effat Zaky, Marowa Abd El Wahab, Shimaa Kamal, Zienab Khalaf \\ Department of Phoniatrics, Faculty of Medicine, Minia University, Minia, Egypt
}

\begin{abstract}
Introduction: Children suffering from Iron Deficiency Anemia (IDA) have shown iron-deficiency associated with psychomotor and cognitive abnormalities and impact language and learning acquisition in children. Children of two years old also demonstrate a decrease in mental investment than non-anemic children, although there is an evident improvement once treatment started. This work aims to establish baseline data about the size and distribution of language disorders among kids with iron deficiency anemia.

Method: This study carried out two groups: The (study group) included 25 children diagnosed with IDA. Compared to another group (control group), had 25 not diagnosed with IDA. According to the language assessment protocol, all children were assessed: Parents interview and history, audiological evaluation, Psychometric evaluation, Arabic Preschool Language Scale-4 "APLS-4 test, Mansoura Arabic Articulatory Test, Complete blood count (CBC), Serum iron and ferritin test.

Results: A statistically significant difference between the study and the control group regarding the (receptive, expressive, and total) row scores. There was a positive fair significant correlation between the receptive and expressive language score and serum iron.

Conclusion: There is evidence that children with Iron Deficiency Anemia show more deficient language development than normal children.
\end{abstract}

Key Words: Anemia, ferritin, iron-deficiencies, language, mentality.

Received: 01 February 2021, Accepted: 07 April 2021

Corresponding Author: Effat Zaky, Department of Phoniatrics, Faculty of Medicine, Minia University, Minia, Egypt, Tel.: +20 1016607002, E-mail: dr_efat_am@yahoo.com

ISSN: 2090-0740, 2021

\section{INTRODUCTION}

Iron deficiency is that the most widespread nutritional deficiency worldwide and an enormous general medical issue, particularly in developing countries. Children affected by Iron Deficiency Anemia (IDA) have shown iron-deficiency associated with psychomotor and cognitive abnormalities, impact language and learning acquisition in children $^{[1]}$.

Many studies carried out during the last decade have shown the adverse effects of iron deficiency on school children and adolescents' cognitive acquisition. Children with IDA had decrease in mental investment compared with non-anemic children, although most of those children show significant improvement after treatment of anemia ${ }^{[2]}$. Many studies detected poor in auditory development in anemic patients and explained that with myelination of the auditory nervous system is postponed in these patients ${ }^{[3]}$.

This work aimed at establishing the baseline data about the size and distribution of language disorders among children with iron deficiency anemia to plan early detection, proper assessment, and intervention to manage these problems if present.

\section{MATERIAL AND METHOD}

This study carried out on fifty children divided to two groups: The study group included 25 children diagnosed with iron deficiency anemia collected from pediatric blood disease clinic at the Minia University Hospital. This group was Compared to another group (control group), which included 25 children not diagnosed with iron deficiency anemia Collected from children coming with their relatives to ENT clinic. Our study was approved by the ethics panel of our University Hospital, Faculty of medicine, Egypt. The parents of children gave a written consent to publish the info contained within this study. )The children in the study group were 15 males $60 \%$ and 10 females $40 \%$ with a median of the age 42 months with age range $3-7$ years. The children in the control group were 13 males $52 \%$ and 12 females $48 \%$, with a median of age 52 months with an age range 3-7years. Children of both groups were matched in age and sex. The Inclusion criteria for both group were the age from 3 to 7 years old, and the children not suffering from any chronic illness. While, Inclusion criteria for the children in the study group were that they had CBC analysis showed microcytic hypochromic anemia (the mean of Hemoglobin Level below -10), the mean of serum 
iron level was below $45 \mathrm{mcg} / \mathrm{dL}$ and the mean of serum ferritin level was below $40 \mathrm{ng} / \mathrm{ml}$ ), while these parameter was normal in the control group.

All children were assessed according to the language assessment protocol in the Phoniatrics Unit, Minia University Hospital. This protocol was classified into:

\section{I-Preliminary Diagnostic Procedures}

Parents interview and history, including a complaint, personal information, personal data, natal, neonatal, and postnatal history, developmental milestones, and early childhood illness.

\section{II-Clinical Diagnostic Aids}

1. Audiological evaluation included hearing assessment and middle ear assessment using immitancemetry (tympanometry or acoustic reflex threshold recording), free Field audiometry or audiometry or auditory brainstem response (ABR).

2. Psychometric evaluation by Intelligence Quotient "IQ" using Stanford Binet Intelligence Scale "5th Arabic version" (SB-5) ${ }^{[4]}$. SB-5 provides an assessment of cognitive and intellectual functions. SB5 has ten subtests two subtests- Nonverbal and Verbal Knowledge (Vocabulary). The Full-Scale IQ combines all ten subtests.

3. Language test by Arabic Preschool Language Scale-4 "APLS-4. This modified scale was used mainly to identify children who had a language disorder or delay. Modified PLS-4 is composed of two subscales, Auditory Comprehension (AC) subscale (it contains 62 items) and Expressive Communication (EC) subscale (it contains 71 items). Modified PLS-4 includes two supplemental assessments, the articulation screening test (for children ages 2y6/12-7years).

4. Mansoura Arabic Articulatory Test "MAAT": A detailed assessment of articulation skills was done by in the Phoniatrics Unit of Mansoura University with the aid of a systematic articulation test that covers all Arabic sounds ${ }^{[5]}$. The Mansoura Arabic Articulation Test (MAAT) consists of 26 items containing 4 sub-items represents each Arabic consonant in the beginning, middle, end, and double positions of familiar words. In addition to 7 items representing the Arabic Vowels contained within familiar words. Each word is represented to the subject in the form of a picture card to be named.

\section{III- Laboratory tests}

1. Complete blood count $(\mathrm{CBC})$ : It was determined by an automated cell counter (Cell Tac ES MEK7300K, NIHON KOHDEN, Japan). Complete blood count $(\mathrm{CBC})$ analyses provide comprehensive information regarding the classification of anemia.
2. Serum ferritin test: It was analyzed by (Cobas e 411, Roche, HITACHI). The ferritin test used venous blood to measure ferritin levels. The ferritin test measured the level of ferritin, the principal iron storage protein in the body.

3. Serum iron test: It was determined by Colorimetric CAB Method. The absorbance of the complex was measured at $623 \mathrm{~nm}$ by a Micro lab 300 analyzers (ELITech Group Clinical Systems, France). A serum iron test measured how much iron was in the serum.

\section{Statistical analysis}

The data were tabulated, coded and analyzed by SPSS software version 20. Descriptive statistics were done by mean, standard deviation for normally distributed numerical variables, by median and interquartile range for not normally distributed numerical variables, while they were done by number and percentage for qualitative variables. Quantitative variables tested for normality by Shapiro Wilk test and all are not normally distributed. MannWhitney test used to determine the statistical difference between the two groups for quantitative variables. Chisquare and fisher's exact test used to determine the statistical difference between the two groups for qualitative variables. Pearson's and Spearman's correlation used to correlate between different variables. The (r) ranged from $(0 \pm 1)$ according to it the degree of correlation determined (0-0.24 weak, 0.25-0.49 fair, 0.5-0.74 moderate and $\geq 0.75$ strong). The level of significance was taken at $p$ value less than 0.05 is significant.

\section{RESULTS}

There were no statistically significant differences between the study group and the control group regarding the age and gender $(P$-value $<0.05)$. The children in the study group were $15(60 \%)$ males and $10(40 \%)$ females, and median of the age was 42 months, the children in the control group were $13(52 \%)$ males and $12(48 \%)$ females and median of the age was 52 months. Non- statistically significant differences were obtained between the study and the control group regarding the consanguinity $P$-value $<0.05$ (Table-1).

Table 1: Comparison between the study and control group regarding the age, sex and Consanguinity

\begin{tabular}{|c|c|c|c|c|}
\hline & & $\begin{array}{l}\text { Patients } \\
\text { (group I) }\end{array}$ & $\begin{array}{c}\text { Control } \\
\text { (group II) }\end{array}$ & \multirow[t]{2}{*}{$P$ value } \\
\hline & & $\mathrm{N}=25$ & $\mathrm{~N}=25$ & \\
\hline \multirow{2}{*}{ Age (months) } & Iqr & $(36-55.5)$ & $(39.5-64)$ & \multirow{2}{*}{0.156} \\
\hline & Median & 42 & 52 & \\
\hline \multirow{2}{*}{ Sex } & Male & $15(60 \%)$ & $13(52 \%)$ & \multirow{2}{*}{0.569} \\
\hline & Female & $10(40 \%)$ & $12(48 \%)$ & \\
\hline \multirow{2}{*}{ Consanguinity } & -ve & $19(76 \%)$ & $18(72 \%)$ & \multirow{2}{*}{0.747} \\
\hline & $+\mathrm{ve}$ & $6(24 \%)$ & $7(28 \%)$ & \\
\hline
\end{tabular}


As shown in (Table -2) there was a statistically significant difference between the two groups regarding the history of cow milk feeding before one year $(48 \%$ in the study group compared to $12 \%$ in control group). There was a statistically significant difference between the two groups regarding the Articulatory errors (68\% in the study group compared to $36 \%$ in control group). There was a statistically significant difference between the two groups regarding the IQ grades (In the study group, 5(20\%) of children had average mentality compared to $20(80 \%)$ in the control group) and (In the study group, 18 (72\%) children had below the average mentality compared to 5 (20\%) in the control group).

Table 2: Comparison between the study and control groups regarding cow milk feeding before 1 year, sociality, articulatory errors and IQ

\begin{tabular}{|c|c|c|c|c|}
\hline & & $\begin{array}{l}\text { Patients } \\
\text { (group I) }\end{array}$ & $\begin{array}{c}\text { Control } \\
\text { (group II) }\end{array}$ & \multirow[t]{2}{*}{$P$ value } \\
\hline & & $\mathrm{N}=25$ & $\mathrm{~N}=25$ & \\
\hline $\begin{array}{l}\text { Cow-milk feeding } \\
\text { before year }\end{array}$ & $\begin{array}{l}\text {-ve } \\
+ \text { ve }\end{array}$ & $\begin{array}{l}13(52 \%) \\
12(48 \%)\end{array}$ & $\begin{array}{c}22(88 \%) \\
3(12 \%)\end{array}$ & $0.012^{*}$ \\
\hline $\begin{array}{l}\text { Articulatory } \\
\text { error }\end{array}$ & $\begin{array}{l}\text { Negative } \\
\text { Positive }\end{array}$ & $\begin{array}{c}8(32 \%) \\
17(68 \%)\end{array}$ & $\begin{array}{c}16(64 \%) \\
9(36 \%)\end{array}$ & $0.024^{*}$ \\
\hline IQ & $\begin{array}{l}\text { MR } \\
\text { Below average } \\
\text { Average }\end{array}$ & $\begin{array}{c}2(8 \%) \\
18(72 \%) \\
5(20 \%)\end{array}$ & $\begin{array}{c}0(0 \%) \\
5(20 \%) \\
20(80 \%)\end{array}$ & $0.0001^{*}$ \\
\hline
\end{tabular}

Fisher's exact test $\quad *$ : Significant difference at $P$ value $<0.05$

There were significant non-statistical differences between the study and the control group regarding the perinatal outcomes, including neonatal cyanosis, jaundice, mode of birth, and birth weight (Table -3). There was a nonstatistical significant difference between the two groups regarding the age of sitting, age of walking, and age of $1 \mathrm{st}$ word. There was a Non-statistical significant difference between the two groups regarding the audiological evaluation $(P>0.05)$ (Table -4).

Table 3: Comparison between the study and control group regarding the perinatal history

\begin{tabular}{|c|c|c|c|c|}
\hline & & $\begin{array}{l}\text { Patients } \\
\text { (group I) }\end{array}$ & $\begin{array}{c}\text { Control } \\
\text { (group II) }\end{array}$ & \multirow[t]{2}{*}{$P$ value } \\
\hline & & $\mathrm{N}=25$ & $\mathrm{~N}=25$ & \\
\hline Cyanosis & $\begin{array}{l}\text {-ve } \\
+\mathrm{ve}\end{array}$ & $\begin{array}{c}22(88 \%) \\
3(12 \%)\end{array}$ & $\begin{array}{c}21(84 \%) \\
4(16 \%)\end{array}$ & 1 \\
\hline Jaundice & $\begin{array}{l}\text {-ve } \\
+\mathrm{ve}\end{array}$ & $\begin{array}{c}15(60 \%) \\
10(40 \%)\end{array}$ & $\begin{array}{c}15(60 \%) \\
10(40 \%)\end{array}$ & 1 \\
\hline Type of labor & $\begin{array}{l}\text { Normal } \\
\text { CS }\end{array}$ & $\begin{array}{c}13(52 \%) \\
12(48 \%)\end{array}$ & $\begin{array}{l}14(56 \%) \\
11(44 \%)\end{array}$ & 0.777 \\
\hline Birth weight & $\begin{array}{l}\text { Average } \\
\text { Low weight }\end{array}$ & $\begin{array}{c}24(96 \%) \\
1(4 \%)\end{array}$ & $\begin{array}{c}25(100 \%) \\
0(0 \%)\end{array}$ & 1 \\
\hline
\end{tabular}

- Chi square test and Fisher's exact test for qualitative data between the two groups

- *: Significant difference at $P$ value $<0.05$
Table 4: Comparison between the study and control group regarding developmental milestone, first word utterance and audiological evaluation

\begin{tabular}{clccc}
\hline & & $\begin{array}{c}\text { Patients } \\
\text { (group I) }\end{array}$ & $\begin{array}{c}\text { Control } \\
\text { (group II) }\end{array}$ & \multirow{2}{*}{ P value } \\
\cline { 3 - 4 } & & $\mathrm{N}=25$ & $\mathrm{~N}=25$ & \\
\hline \multirow{2}{*}{ Age of sitting } & Median & $\begin{array}{c}(6-11.5) \\
8\end{array}$ & $\begin{array}{c}(6-8) \\
7\end{array}$ & \multirow{2}{*}{0.145} \\
Age of walking & Median & $(16-24)$ & $(12-18)$ & \multirow{2}{*}{$0.0001^{*}$} \\
Age of 1st word & Median & 18 & 12 & \\
utterance & & $(15-24)$ & $(13-18)$ & \multirow{2}{*}{$0.035^{*}$} \\
Audiological & Bilateral normal & $24(96 \%)$ & $22(88 \%)$ & \\
evaluation & CHL & $0(0 \%)$ & $3(12 \%)$ & 0.130 \\
& SNHL & $1(4 \%)$ & $0(0 \%)$ & \\
\hline
\end{tabular}

Mann Whitney test for non-parametric quantitative data (expressed by median) between the two groups

*: Significant difference at $P$ value $<0.05$

There were statistically significant differences in the lab results between the two groups: In the study group, $25(100 \%)$ children who had CBC show Microcytic Hypochromic Anemia while in the control group GII, $25(100 \%)$ children had normal (CBC). Regarding the Hemoglobin level; in the study group, the mean HB level was $(9.5 \pm 0.9) \mathrm{g} / \mathrm{dl}$, while it was $(12.3 \pm 0.5) \mathrm{g} / \mathrm{dl}$ in the control group. Regarding serum iron level; in the study group, it was $(41.1 \pm 3.6)$ white it was $(71.8 \pm 12.6) \mathrm{mcg} /$ $\mathrm{dL}$ in control. Serum ferritin level; in the study group, it was $(9.3 \pm 1.4) \mathrm{ng} / \mathrm{ml}$ while it was $(33.4 \pm 12.1) \mathrm{ng} / \mathrm{ml}$ in the control group (Table -5).

Table 5: Comparison the results of lab. Tests between the study groups (complete blood count, hemoglobin level, $\mathrm{S}$ ferritin level and iron level)

\begin{tabular}{|c|c|c|c|c|}
\hline & & $\begin{array}{l}\text { Patients } \\
\text { (group I) }\end{array}$ & $\begin{array}{c}\text { Control } \\
\text { (group II) }\end{array}$ & \multirow[t]{2}{*}{$P$ value } \\
\hline & & $\mathrm{N}=25$ & $\mathrm{~N}=25$ & \\
\hline $\mathrm{CBC}$ & $\begin{array}{l}\text { Normal } \\
\text { Microcytic } \\
\text { hypochromic } \\
\text { anemia }\end{array}$ & $\begin{array}{c}0(0 \%) \\
25(100 \%)\end{array}$ & $\begin{array}{c}25(100 \%) \\
0(0 \%)\end{array}$ & $0.0001^{*}$ \\
\hline $\mathrm{HB}$ & $\begin{array}{l}\text { Range } \\
\text { Mean } \pm \text { SD }\end{array}$ & $\begin{array}{l}(7.7-11) \\
9.5 \pm 0.9\end{array}$ & $\begin{array}{c}(11.4-13.5) \\
12.3 \pm 0.5\end{array}$ & $0.0001^{*}$ \\
\hline S. Iron & $\begin{array}{l}\text { Range } \\
\text { Mean } \pm \text { SD }\end{array}$ & $\begin{array}{c}(33.6-47.3) \\
41.1 \pm 3.6\end{array}$ & $\begin{array}{c}(50-90) \\
71.8 \pm 12.6\end{array}$ & $0.0001^{*}$ \\
\hline S. Ferritin & $\begin{array}{l}\text { Range } \\
\text { Mean } \pm \text { SD }\end{array}$ & $\begin{array}{l}(6.7-12) \\
9.3 \pm 1.4\end{array}$ & $\begin{array}{c}(19-54) \\
33.4 \pm 12.1\end{array}$ & $0.0001^{*}$ \\
\hline
\end{tabular}

Independent samples $\mathrm{T}$ test for parametric quantitative data between the two groups Fisher's exact test for qualitative data between the two groups

*: Significant difference at $P$ value $<0.05$

There was a statistical significant difference between the study and the control group as regarding the raw scores of the receptive, expressive and total scores, the receptive, expressive and total standard scores and the receptive, expressive and total language age language 
age as indicated in (Table -6). There was a statistically significant difference between the study and the control group regarding language development $(P<0.05)$; in the study group, $4(16 \%)$ children had normal language development and $21(84 \%)$ children had delayed language development. In the control group, 20 (80\%) children had normal language development $5(20 \%)$ children had delayed language development as indicated in (Table -7).

Table 6: Comparison between the study and control group regarding language test

\begin{tabular}{|c|c|c|c|c|}
\hline & & $\begin{array}{l}\text { Patients } \\
\text { (group I) }\end{array}$ & $\begin{array}{c}\text { Control } \\
\text { (group II) }\end{array}$ & \multirow[t]{2}{*}{$P$ value } \\
\hline & & $\mathrm{N}=25$ & $\mathrm{~N}=25$ & \\
\hline $\begin{array}{l}\text { Receptive } \\
\text { language } \\
\text { row score }\end{array}$ & $\begin{array}{l}\text { Range } \\
\text { Mean } \pm \text { SD }\end{array}$ & $\begin{array}{c}(29-55.5) \\
34\end{array}$ & $\begin{array}{c}(47-60) \\
57\end{array}$ & $0.001^{*}$ \\
\hline $\begin{array}{l}\text { Expressive } \\
\text { language } \\
\text { row score }\end{array}$ & $\begin{array}{l}\text { Range } \\
\text { Mean } \pm \text { SD }\end{array}$ & $\begin{array}{c}(29-54) \\
33\end{array}$ & $\begin{array}{c}(51-70) \\
60\end{array}$ & 0.0001 \\
\hline $\begin{array}{l}\text { Total language } \\
\text { row score }\end{array}$ & $\begin{array}{l}\text { Range } \\
\text { Mean } \pm \text { SD }\end{array}$ & $\begin{array}{c}(57.5-108.5) \\
68\end{array}$ & $\begin{array}{c}(98.5-130) \\
117\end{array}$ & 0.0001 \\
\hline $\begin{array}{l}\text { Standard score } \\
\text { of receptiv }\end{array}$ & $\begin{array}{l}\text { Range } \\
\text { Mean } \pm \text { SD }\end{array}$ & $\begin{array}{c}(54-83) \\
60\end{array}$ & $\begin{array}{c}(85-112) \\
94\end{array}$ & 0.0001 \\
\hline $\begin{array}{l}\text { Standard score } \\
\text { of expressiv }\end{array}$ & $\begin{array}{l}\text { Range } \\
\text { Mean } \pm \text { SD }\end{array}$ & $\begin{array}{c}(52-63.5) \\
53\end{array}$ & $\begin{array}{c}(73-112) \\
89\end{array}$ & $0.003^{*}$ \\
\hline $\begin{array}{c}\text { Standard } \\
\text { score of total }\end{array}$ & $\begin{array}{l}\text { Range } \\
\text { Mean } \pm \text { SD }\end{array}$ & $\begin{array}{c}(51-70) \\
51\end{array}$ & $\begin{array}{c}(80-118) \\
90\end{array}$ & 0.0001 \\
\hline $\begin{array}{l}\text { Language age } \\
\text { of receptive }\end{array}$ & $\begin{array}{l}\text { Range } \\
\text { Mean } \pm \text { SD }\end{array}$ & $\begin{array}{c}(29-66.5) \\
36\end{array}$ & $\begin{array}{c}(54-75) \\
69\end{array}$ & $0.001^{*}$ \\
\hline $\begin{array}{l}\text { Language age } \\
\text { of expressive }\end{array}$ & $\begin{array}{l}\text { Range } \\
\text { Mean } \pm \text { SD }\end{array}$ & $\begin{array}{c}(26.5-55.5) \\
31\end{array}$ & $\begin{array}{c}(54-75) \\
65\end{array}$ & 0.0001 \\
\hline $\begin{array}{l}\text { Language } \\
\text { age of total }\end{array}$ & $\begin{array}{l}\text { Range } \\
\text { Mean } \pm \text { SD }\end{array}$ & $\begin{array}{c}(27-61) \\
31\end{array}$ & $\begin{array}{c}(54.5-74) \\
67\end{array}$ & $0.0001^{\prime}$ \\
\hline
\end{tabular}

Chi square test and Fisher's exact test for qualitative data between the two groups

- *: Significant difference at $P$ value $<0.05$

Table 7: Comparison between the study and control groups regarding the language development

\begin{tabular}{clccc}
\hline & & $\begin{array}{c}\text { Patients } \\
\text { (group I) }\end{array}$ & $\begin{array}{c}\text { Control } \\
\text { (group II) }\end{array}$ & \multirow{2}{*}{ P value } \\
\cline { 2 - 3 } & $\mathrm{N}=25$ & $\mathrm{~N}=25$ & \\
\hline \multirow{2}{*}{$\begin{array}{c}\text { Language } \\
\text { development }\end{array}$} & $\begin{array}{l}\text { Normal language } \\
\text { Delayed language } \\
\text { development }\end{array}$ & $\begin{array}{c}4(16 \%) \\
21(84 \%)\end{array}$ & $\begin{array}{c}20(80 \%) \\
5(20 \%)\end{array}$ & \multirow{2}{*}{$0.0001^{*}$} \\
\hline
\end{tabular}

- Fisher's exact test for qualitative data between the two groups

- *: Significant difference at $P$ value $<0.05$

A positive moderate significant correlation between IQ score and with serum iron. A positive moderate significant correlation between the total language score and with serum iron. There was a positive fair significant correlation between the receptive language score and serum iron. A positive moderate significant correlation between the expressive language score and with serum iron (Table -8).
Table 8: Correlation between Serum iron and IQ, Receptive, expressive and total language score

\begin{tabular}{lcc}
\hline & \multicolumn{2}{c}{ Serum iron } \\
\hline IQ & Pearson's r & P value \\
Receptive language age & 0.53 & $0.0001^{*}$ \\
Expressive language age & 0.49 & $0.0001^{*}$ \\
Total language age & 0.51 & $0.0001^{*}$ \\
\hline
\end{tabular}

Pearson's correlation: $\quad P$ value $<0.05$ (significant)

\section{DISCUSSION}

Several micronutrients influence the functional performance of children; these effects could begin as early as the period of fetal development. Iron deficiency anemia (IDA,) is the most common micronutrient deficiency worldwide and the World Health Organization (WHO) recognized $25 \%$ of the world's population, had IDA, ${ }^{[6]}$. Iron is an essential nutrient for the average growth, health, survival of children, their normal mental and motor development, and cognitive functioning. Individuals who had iron deficiency anemia or chronic iron deficiency were associated with poor outcomes evident in decreased IQ, motor and cognitive scores, and low academic performance despite iron therapy during infancy ${ }^{[7]}$.

This study aimed at investigating the baseline data for the distribution of language disorders among children diagnosed with Iron Deficiency Anemia (study group) compared to children in control group (who were not diagnosed with Iron Deficiency Anemia). The two groups were matched as much as possible in their sociodemographic data (age and sex of children) to construct a plan of early detection, proper assessment, and intervention to manage and treat these problems if possible.

Regarding the history of cow milk feeding before 12 months of age, the current results revealed a statistically significant difference. $48 \%$ of the study group children had a history of cow milk feeding compared to $(12 \%)$ of the control group. The adverse effects of cow milk on iron nutritional status are thought to be due to cow milk's low iron content. Cow milk also causes occult intestinal blood loss in many infants and contains potent iron absorption inhibitors from the diet. Our result were similar to "Ziegler ${ }^{[8]}$ who reported that feeding cow milk to infants is strongly associated with diminished iron nutritional status and increased ID risk. These results explained the increased incidence of delayed language in our study group as $48 \%$ had breast feeding during the first year of life.

Significant statistical differences were present between the two groups regarding the IQ; where $72 \%$ of children of the study group had below average mentality. Also, a positive moderate significant correlation between IQ score and the total language score with serum iron. The 
Iron-deficient anemic children may explain this result or chronically iron-deficient children from the infancy period were evident to have lower IQ, motor and cognitive scores, and low academic performance. This study was consistent with Hurtado et al..$^{[9]}$ who showed that children younger than ten years with IDA had an increased risk of moderate mental retardation. Also, they reported that the use of multi-nutrient food supplements containing iron or folic acid together with iron demonstrated changes in intellectual development. Our results disagreed with Dissanayake et al. ${ }^{[10]}$ as they concluded that IDA doesn't play a big role in school-going adolescent educational performance and intelligence. This differences between the two results may be due to difference between the ages of children between the two studies and use different testes to measuring intelligence.

Regarding the Articulation test results; where (68\%) in the study group had articulatory errors compared to $(36 \%)$ in the control group. This result was in agreement with Santos et al. ${ }^{[2]}$ Who reported that children with Iron deficiency anemia have lower language development than children without anemia on tasks involving all language aspects. This result was explained by the fact that (84\%) had delayed Language, which may affect Phonological development.

Statistically significant differences between the study and the control group regarding language development was noticed. In the study group, $(84 \%)$ of children had delayed language development. In comparison $(20 \%)$ of children had delayed language development in the control group. This was explained by the finding that $72 \%$ of the children in the study group with IDA had below average mentality. Also, there was a significant positive correlation between the expressive and total language age with serum iron levels. These results agree with Beltrán-Navarro et $\mathrm{al}^{[11]}$, who reported that infants with chronic IDA showed significantly lower scores on Language, environmental sound perception, and motor measures in comparison to infants with a standard iron nutritional status. Also, Santos et $a .^{[2]}$ reported that children with anemia have lower language development than children without anemia on tasks involving reception and cognitive language aspects. On the other hand, Glazer and Bilenko ${ }^{[12]}$ reviewed ten longitudinal and clinical trials. They might not evaluate a causal relationship between iron deficiency anemia, cognitive and mental development in childhood, which plays an important role in language development.

Regarding the language test results, there was a statistically significant difference between the study group and the control group. We found a positive fair significant correlation between the receptive language score and (decreased or low) serum iron levels. A positive moderate considerable correlation between low serum iron levels and the expressive and the total language scores was also found. This result was in agreement with the study of Glazer and Bilenko ${ }^{[12]}$, who reported that the intervention trials with iron supplementation to affected children was associated with an improvement in Language and mental developmental test scores. On the opposite hand, the results aren't in agreement with Youssef et al. ${ }^{[13]}$ who reported that Language evaluations employing a standardized and valid test for language assessment of children showed equal scores on the index of perceptive, expressive, and total language quotients for anemic and non-anemic children. We think the differences between our results and the study referred to be attributed to the use of different parameters of diagnosis of IDA in children as, the level of serum iron, serum ferritin which were more accurate in the diagnosis of our study cases.

Our study showed that $4 \%$ of children in the study group were Brain-Damaged Motor Handicapped children. Our interpretation is that iron is significant to multiple aspects of brain function, including oxidative metabolism, myelination, and neurotransmitter synthesis. Atypical iron concentration within the basal ganglia is related to neurodegenerative disorders in aging and cognitive deficits. This concurs with Larsen et al. ${ }^{[14]}$, who found that tissue iron's developmental trajectory within the putamen is said to individual differences in cognitive ability. Individuals with diminished iron accumulation even have lower cognitive performance in late adolescence and early adulthood.

\section{CONCLUSION AND RECOMMENDATION}

There's evident that children with Iron Deficiency Anemia show poorer language development as compared to normal children. The necessity for diagnosis and treatment of youngsters with IDA as soon as possible, preferably no later. This study poses several challenges for the behavioral pediatrician who may have children with IDA in his or her practice. It's important to watch these children frequently and closely. Recommendation for folks of children with IDA for early Phoniatrics consultation so as to early detection and proper management of any language disorders. And to stop adverse effects which will last an extended period and have a negative impact on learning capability and acquisition of professional skills

\section{CONFILICT OF INTERESTS}

There are no Conflicts of Interest.

\section{REFERENCES}

1. Schirmer CR, Fontouraand DR and Nunes ML. Distúrbios da aquisição da linguagem e da aprendizagem. Jornal de pediatria, 2004; 80(2): 95-103.

2. Santos JS, Lemos S, Rates $M$ and Lamounier J. "Hearing abilities and language development in anemic children of a public daycare center." Pro-fono: revista de atualizacao cientifica, 2008; 20(4): 255-60.

3. Orellana JD, Lourençoand EP and Santos V. Estado nutricional e anemia em crianças Suruí, Amazônia, Brasil. Jornal de pediatria, 2006; 82(5): 383-88. 
4. Roid GH and Barram RA. Essentials of StanfordBinet intelligence scales (SB5) assessment, John Wiley \& Sons, 2004.

5. Abou-Elsaad TH, Baz H and El-Banna. "Developing an articulation test for Arabic-speaking schoolage children". Folia Phoniatrica et Logopaedica, 2009; 61(5): 275-82.

6. De Benoist, B., M. Cogswell, I. Egli and E. McLean (2008). "Worldwide prevalence of anaemia 19932005; WHO Global Database of anaemia."

7. Swaminathan B, Edward $\mathrm{S}$ and Kurpad AV. "Micronutrient deficiency and cognitive and physical performance in Indian children". Eur J Clin Nutr, 2013; 67(5): 467-74.

8. Ziegler EE. Consumption of cow's milk as a cause of iron deficiency in infants and toddlers. Nutr Rev, 2011; 69: 37-42.

9. Hurtado EK, Claussen AH and Scott KG . Early childhood anemia and mild or moderate mental retardation. The American journal of clinical nutrition, 1999; 69(1): 115-19.
10. Dissanayake D, Kumarasiri P, and Dissanayake D - The association of iron status with educational performance and intelligence among adolescents. Ceylon Med J, 2009; 54(3): 75-9.

11. Beltrán-Navarro $B$, Matute E, Vásquez-Garibay E and Zarabozo D . "Effect of chronic iron deficiency on neuropsychological domains in infants." Journal of child neurology, 2012; 27(3): 297-303.

12. Glazer Y and Bilenko N. Effect of iron deficiency and iron deficiency anemia in the first two years of life on cognitive and mental development during childhood. Harefuah, 2010; 149(5): 309-14.

13. Youssef MA, Hassan ES and Yasien DG. Effect of Iron Deficiency Anemia on Language development in Preschool Egyptian children. International Journal of Pediatric Otorhinolaryngology, 2020; 110-14.

14. Larsen B, Bourque J, Moore M, Adebimpe A and Et al. Longitudinal development of brain iron is linked to cognition in youth. Journal of Neuroscience, 2020; 40(9): 1810-18. 